\title{
THE ROLE OF SOCIODRAMA IN ENGLISH SPEAKING CLASS
}

\author{
Berita Mambarasi Nehe \\ STKIP Setia Budhi Rangkasbitung \\ Rangkasbitung, Indonesia \\ Berita.al@stkipsetiabudhi.ac.id
}

\begin{abstract}
This study aims to improve the process of students' speaking skill through sociodrama method on students of English Department of STKIP Setia Budhi Rangkasbitung in Banten region. The participants include 33 students in the third semester. This study uses qualitative descriptive to draw the phenomenon in the classroom when sociodrama applied. Class activity, learning material, class structure in applying sociodrama, student' perception, sociodrama value, and sociodrama tasks are described to understand the class applied by sociodrama. From the research result, it can be concluded that learning by using sociodrama based task is an effective way and provide students to produce language frequently with the groups and grow student' motivation well.
\end{abstract}

\section{Keywords: English Speaking Skill, Sociodrama Method}

\section{INTRODUCTION}

Speaking is important for language learners. Besides having a role in communication, speaking also can be a facility for language acquisition and development. Speaking is considered as the most important skill when learning a foreign language because this is a basic ability for communication (Oradee, 2013). Mastery of English speaking skills is the main thing for both second and foreign language learners (Richards, 2008). This virtue makes speaking skills important to learn as a form to express thoughts, express feelings, reveal facts, to understand thoughts, ideas and feelings of others and the learners need to develop their speaking skills as a form of their existence in language learning. The foreign language in this study is English 
which is the language that is being studied by students of the English education study program about speaking lesson, they learn to speak to build good communication with their interlocutors.

Speaking skills are difficult to develop if it's not trained continuously and can be done with colleagues in the classroom in order to facilitate speaking skills, enrich the use of vocabulary, improve the linguistic order, complete speech vocabulary, sentences, train hearing so catch message easily from the other person, and train the understanding of every conversation that occurs with the other person. According to Harmer there are three main reasons for asking students to speak in the classroom, first that speaking activities help the opportunity to practice/practice real-life talk in a comfortable classroom atmosphere, the second is speaking tasks give feedback for students and teachers, and the third the student has more opportunity to use the elements of diverse languages that they have, so the use of elements of language will occur more automatically (Harmer, 2007). Continuous speaking practice and assignment patterns given by giving a lot of talk space so that the learner will be able to develop his speaking skills optimally.

Based on the pre-observational results, the initial conclusions were obtained that the causes of the low student speaking skills were caused by three things, namely between linguistic factors, personality factors, and class activities.

The first is Linguistic factors that causes of low student speaking skills are related to aspects of speaking. First aspect of pronunciation, there are still many students of STKIP Semester 2 of English Education Study Program Setia Budhi Rangkas count failed to say English words for example the production of sound / $\mathrm{f} /$ changes to sound / p / example first, follow, five, etc. Related words with sound / f/. The factor is that the Mother's language is still thick and is used by students, namely Sundanese, where most Sundanese speakers find it difficult to pronounce sounds / f/. The sound / ght / changes to /..g/i example word: right, fight, eight, light, height, might, and so on. Both aspects of vocabulary, students are still not able to produce a conversation maximally because of limited vocabulary. The three aspects of grammar, students are still unable to use 
grammar correctly such as material tenses, capital auxiliary, gerund, to be and others. The four aspects of fluency, because of the pronunciation of many failed, lack of vocabulary, and not much grammar has been mastered causing the conversation to be hampered and not smooth. The five aspects of understanding, students still do not understand when the explanation of the material is given, and when a question and answer occurs the students still do not understand the simple questions and sometimes must be translated into Indonesian first after that they answer in English.

These two personality factors are causing low student speaking skills. Not all students who are attending speaking 2 have the courage to speak. Many of them are anxious about class conditions, afraid of being wrong when issuing their ideas, worrying about having to speak later making mistakes so that they get a crisis of confidence that ultimately chooses silent to take safe steps. Maslow in (Pecaski McLennan, 2008) states that before students are bound in the learning process, their basic needs must be fulfilled, namely they must feel safe in the classroom. Therefore it is very necessary for lecturers to make pleasant conditions in the classroom.

The third is classroom activities, as long as the researchers observed in several meetings in the class Speaking 2 , the researchers saw that the students had studied many discussions to develop speaking skills but they were not placed in a real communication room in the classroom. And it just happened that they are required to complete individual Speaking tasks such as telling or describing something done by memorizing. The teaching pattern of Speaking courses has been using form-based instruction (structured learning patterns). This kind of activity only benefits to students who have good speaking skills whereas for other students this kind of speaking activity is a scary thing because their English speaking skills are low which causes their learning conditions is under pressure. Students who dare to tell the story in front of the class are only about 3 people so that the learning process of Speaking only wastes time in the classroom with them having to memorize the text to tell the story (although not performing) and this activity does not succeed to make all class members speak and this situation 
is ineffective to develop English speaking skills.

The weakness of the method used so far is individual and only benefits to smart students, the learning pattern does not give more experience to students, the learning is not challenging and makes students passive in class, students are demanded according to their crafts and abilities, class is dominated by lecturers, students do not have the courage to appear because of their individual learning patterns, their learning is transactional and does not lead students to establish communication and interact in English with their friends so that the competence of communication of students does not develop.

Based on the presentation of the results of this pre-study, the authors attempt to create interesting, challenging, effective, efficient learning that can motivate students to be active, creative in groups and alone, able to think critically and analytically, able to communicate freely in a controlled manner. Learning is given in ways that are interesting, varied, and more centered on learners. The method applied is the sociodrama method. The sociodrama method is applied as an alternative to assist the students in developing their language skills.

Sternberg and Garcia (Sternberg \& Garcia, n.d.) also explained that sociodrama has holistic or comprehensive uses, namely sociodrama, is a kinesthetic modality that binds emotions, thoughts, and body movements. These three things are very helpful in the development of students' speaking skills if they are trained on an ongoing basis. Sociodrama is a group action method that relates to the roles shared with others (Sternberg and Garcia: 2000, 12). The focus of sociodrama is on the group so that the learning patterns formed in the Speaking 3 course are in groups. This group has the opportunity to carry out roles that focus on social problems and problem solving (Upstream, 2004). Kellerman in Browne also stated that sociodrama is a method for social change and a method for intercultural communication. The gap that occurs in the social can actually be pursued through sociodrama.

The advantage of the sociodrama method is learning with groups that help and strengthen each other in the process of interaction with their friends, the learning is centered on students and 
lecturers only as facilitators, all students are involved in learning activities, this method provides a lot of experience in learning to speak English for students because they practice the scene with group members, students can empathize with what happens to others because the results of the roles played out of their own capacities, respect for each other because they feel that one family in learning can provide the best in learning. This is supported also by Smilansky's statement in Almon (2008:

1) regarding the superiority of sociodrama which affects cognitive creative activities and social emotional activity. Cognitive creative activities include better verbal language, enriching vocabulary, better language comprehension, better language levels, better problem solving strategies, curiosity to be greater and increased, better understanding of others, Intellectual competence is higher, cooperation between friends is better, reducing the level of negative competition and reducing tension between group members, and more group activities. Furthermore, social emotional activities about learners play more with their friends, better understanding of others, a sense of empathy for others increases, able to control a passionate desire for the heart, able to regulate emotions well and have a good sense of social, has good innovation, has good imagination, is able to give better and greater attention, carry out tasks that are given well. Cognitive and social activities will greatly help students interact with their friends in displaying sociodrama stories.

(Scarcella, 1978) suggests that sociodrama can be used effectively to develop communication skills first by participating in some scenes, language learners producing new sentences based on their behavior or the spontaneous arrangement produced by them. Second, as in real-life communication, sociodrama learners rearrange the use of language based on social context. The three sociodrama teach social interaction as a condition for communication. The sociodrama method can help students to produce many sentences from scenes related to social issues. The focus of the research is on the process of learning to improve English speaking skills through the sociodrama method.

\section{LITERATURE REVIEW}

Speaking is one of the productive aspects of communicative competence 
and speaking is an important part of foreign language learning. Speaking is the use of an active language to convey meaning in order for others to understand them (Cameron, 2011). Further skills to speak fluently are the result of grammatical teaching and vocabulary. And speaking is a more complex activity that not only involves grammar and vocabulary but also involves many aspects such as governing skills and other knowledge (Thornbury \& Scott, 2012).

Based on theories about speaking skills, the authors conclude that speaking skills are a productive skill that occurs between two or more people interactively to express thoughts verbally by mastering linguistic and non-linguistic aspects. Speaking skills are not enough just by mastering the principles of language structure, the principles of language utterance and the delivery of ideas, thoughts, or feelings of skill to others, but also related to motion, matters relating to emotions and all forms of interaction. Linguistic aspects related to speaking aspects are pronunciation, vocabulary, grammar, fluency, and understanding to convey messages by involving production, acceptance, and information processing.
Sternberg and Garcia state that sociodrama is a group learning process that focuses on training to solve human relations problems. Sociodramas help group members to express thoughts, look for values and feelings, and provide opportunities to practice new behaviors (Sternberg \& Garcia, n.d.). Furthermore Sternberg and Garcia Sosiodrama is affirmed as a kinesthetic modality that includes emotions, thoughts, and gestures.

Sociodrama is a teaching method which in practice learners get the task of the teacher to dramatize social situations that contain a problem so that students can solve a problem that arises from a social situation (Sagala S, 2006). From some of these opinions, it can be concluded that the method of sociodrama is a method of learning where the teacher / lecturer provides opportunities for students / students to solve problems that occur in the context of social relations by dramatizing these problems through a drama that includes three aspects, namely cognitive, affective, and psychomotor.

\section{RESEARCH METHODOLOGY}

The place of study of this action is in the English Education Study Program 
STKIP Setia Budhi Rangkasbitung, Lebak District, Banten Province where researchers perform the task. The timing of this action research in odd semester starts from September to November of Academic Year 2015/2016. This research is a descriptive qualitative research describing learning phenomenon with sociodrama in learning speaking course.

\section{RESEARCH RESULT}

Research results on the process of learning English speaking skills through Sociodrama method include several things, namely.

\section{a. Class Activity}

At the beginning of the meeting, students were told that they would get treatment in the classroom using the sociodrama method. Before they are given a solid activity in the classroom, the psychological state of the student must be in a calm and relaxed state so that the learning with the sociodrama method works well. Maslow in McLennan that before students are tied up in the learning process, their basic needs must be met ie they should feel safe in the McLennan class: 2008, 81). The sense of safety and comfort of students must be conditioned as well as possible so that learning goes well. Starting from the first meeting, the lecturer asked the students not to use Indonesian language, the lecturer asked the students to continue to speak English during the class even though they just want to borrow like a book, pen or other things they have to use English. The tasks undertaken by students at first they find it difficult to create their own drama script, but over time and direction from their lecturers can create their own drama script to be displayed with the group in front of the class. The tasks assigned to them are about social life close to their lives and this social story is able to help express students' thoughts in English easily and because of their frequent use of English starting with small things they are getting less used to interact using English with friends.

\section{b. Learning Materials}

Learning materials are taken from several references, namely from Speaking books and from the internet and learning topics are packaged in syllabus courses. Materials learned by students are studied together in groups. The material that will be displayed when the learning process takes place is that the drama material is created by the 
student according to the topic of learning while the additional task material has been prepared by the lecturer to be studied and displayed in the next meeting in the form of homework with the group.

\section{c. Speaking Class Structure with}

\section{Sociodrama Method}

Classes are built with several stages: first, group formation, lecturers ask students to sit with their groups to make and discuss the stories that will be displayed. Second, students make stories based on their own imagination based on the learning topics that are being learned at that time. Third, after they are ready with the script, they practice the drama that has been made so that their understanding is attached to the social story. Fourth, after training they were asked to display their work with the group, sometimes in the classroom and sometimes in an open hall according to the agreement with students. The way in McLennan states that a comfortable and large space for drama will give students free movement (McLennan: 2008). So that sociodrama performances are held in two classrooms and open halls to provide a sense of comfort to students. fifth, after they present the drama, the lecturer asks the students to evaluate the sociodrama appearance both individually and in groups.

\section{d. Student Perceptions of}

Sociodramas in Classes Speaking English as a Foreign Language

The general finding in this study is that most students view the sociodrama method as a way to help use English in communication in English as a foreign language class. They stated that the giving of the sociodrama method in the speaking class in the Speaking 3 course provided an opportunity to improve English speaking skills because this method was carried out with the group so that there was a direct interaction with the use of English. The class becomes active with this method because all students are asked to practice and display sociodramas in front of the class so that what happens is speaking English is truly dominated by students and this is what is expected that the class speaks its learning patterns must be centered on students and lecturers just become facilitators and companion if students feel they need help to ask questions or have problems in learning.

e. Sociodrama Values in English

Speaking Skills Learning 
Sociodrama helps people to explain self-worth, solve problems, make decisions, gain greater understanding, learn to play roles in more satisfying ways, practice new roles, and become more spontaneous and cheerful (Patricia Sternberg and Antonia Garcia : 2000, 12). The results of the learning process with the sociodrama method form the values that develop when learning speaking skills take place and have been able to provide improvements to the quality of the learning process and the learning outcomes of students' English speaking skills. Action research implementation has provided evidence that the application of the sociodrama method can improve students' English speaking skills on aspects of pronunciation, vocabulary, grammar, fluency, and understanding. This method has also been able to foster student attitudes towards a positive direction, including cooperation, responsibility, care, communication and interaction, and motivation in learning Speaking 3 courses. Class nuances become active because they are studentcentered. Students directly interact with their friends by displaying stories that they have made themselves, they diligently work on the task of making scripts, are serious about practicing drama, they also help each other to friends who still have difficulty in speaking, they really enjoy speaking activities because of their mental condition not under pressure. They are free to explore with groups to make more diverse characters in their drama stories and explore developing issues, dare to take risks in learning, dare to try, they find social problems and then developed into a social story, and they are able to group together solve existing problems.

Learning speaking skills through the sociodrama method is formed in group learning, they help each other and they uphold the value of cooperation in groups and through the learning process students also volunteer to help group members and strengthen each other so that learning motivation is higher.

From the results of observations and interviews that students get a great experience with the method of sociodrama. A strong desire inside because he saw his friends acting made them continue to study diligently in order to provide good sociodrama offerings. External influences (friends) have a tremendous influence on the motivation of individuals to continue to 
be committed in learning and each meeting is told the strengths and weaknesses of their sociodrama offerings so that they are aware and continue to improve themselves to be able to speak English properly and correctly.

\section{f. Sociodrama Tasks}

The success of learning using the sociodrama method is very effective if it is supported by several things including learning media, interesting and effective task instructions, learning resources, pleasant learning spaces, and students' motivation to study seriously in order to improve English speaking skills. There are two types of assignments given to students, namely direct assignments when learning and additional assignments to be completed at the next meeting. These tasks are interactive, involving more than one person.

Researchers apply various task strategies to improve student speaking skills. In cycle 1, researchers conducted Speaking learning by asking students to display sociodrama without the help of homework and only focus on making stories in the class with the group. Cycle 2, researchers and collaborators discuss to provide more student speaking activities to help students practice a lot in terms of speaking. Students are given drama group assignments with drama texts provided by the researchers before they present their own sociodramas. In cycle 3 the researcher continues to provide homework and training in the classroom consistently.

\section{CONCLUSION}

Based on the results of research and discussion and submission of research problems, it can be concluded in general that learning with a task-based sociodrama method is an effective method and provides learning opportunities for students to produce and use English as often as possible with group members as well as foster high motivation to explore language interactively. Sociodramas also provide a positive improvement in aspects of knowledge, attitudes and behavior in developing English speaking skills. A pleasant classroom environment influences students' attitudes and motivation in learning. All these psychological elements help a good class community. Students work together in groups by completing tasks assigned by lecturers. The conclusions based on the submission of research problems are as follows. 
The process of improving English speaking skills in students of STKIP Setia Budhi Rangkas English Education Study Program increased through the application of the sociodrama method. The results of the study for three cycles proves that the application of the sociodrama method can not only improve speaking skills in terms of linguistic knowledge but also improve the ability of students to conduct sociodrama activities during the learning process in aspects of attitudes and behavior. The application of the sociodrama method shows continuous improvement results in each cycle, this is indicated by several things, namely increasing student cooperation when they make sociodrama texts, increasing student responsibility when given assignments and being able to complete sociodrama manuscripts to be displayed at each meeting, growing student concern to help members who lack English speaking, increase communication skills and student interaction due to ongoing training sessions between group members, and student motivation continues to increase in following the learning process of Speaking 3 courses.

\section{a. Suggestion}

Based on the conclusions and implications, there are several suggestions that need to be conveyed to some parties as a form of participating in the development of knowledge in English learning. Those suggestions are follows:

1. Lecturers become models in the use of English by providing direct examples for students. This method will have an optimal impact on student learning outcomes.

2. Students of the English Language Study Program need to get used to speaking English as often as possible and this should be supported by all parties in providing positive support for study programs, lecturers, students, or other parties. This pattern of habituation can be applied in the classroom or outside the classroom. Lecturers are expected to be more innovative in carrying out the learning of Speaking courses or other courses that have to do with speaking activities by packing interesting learning materials from simple levels to complex levels of interest. Learning methods must be adapted to the conditions of students so that they are not boring, especially 
making students reluctant to speak English.

3. The sociodrama method can be applied in schools both in primary and secondary schools. The implementation of this method must still pay attention to students' level of ability and give students freedom so that they can share ideas together in English so that students can practice speaking in earnest in a fun learning pattern.

4. With some limitations in this study, other researchers are expected to conduct a more comprehensive study on the application of sociodrama methods in improving language skills (listening, speaking, reading, and writing) with research areas in various other schools and colleges.

\section{REFERENCES}

Almon, Joan. The Social, Emotional, and Intellectual Benefits of Play Excerpted from

"The Vital Importance of Play in Early childhood Education". 2008.

Cameron, L. (2011). Teaching

Languages to Young Learners.

New York: Cambridge University Press.

Harmer, J. (2007). How to Teach
English (Second Edition). ELT

Journal, 62(3), 313-316.

https://doi.org/10.1093/elt/ccn029

Oradee, T. (2013). Developing

Speaking Skills Using Three

Communicative Activities

(Discussion, Problem-Solving, andRole-Playing). International

Journal of Social Science and

Humanity, 533-535.

https://doi.org/10.7763/IJSSH.201

2.V2.164

Pecaski McLennan, D. M. (2008).

Kinder/caring: Exploring the use and effects of sociodrama in a kindergarten classroom. ProQuest Dissertations and Theses, 2(October), 291. Retrieved from http://search.proquest.com/docvie $\mathrm{w} / 304560229$ ? accountid $=14553 \%$ 5Cnhttp://openurl.library.uiuc.edu/ sfxlc13?url_ver=Z39.88-

2004\&rft_val_fmt=info:ofi/fmt:ke $\mathrm{v}: \mathrm{mtx}$ :dissertation \&genre $=$ dissertat ions+\%26+theses\&sid=ProQ:ProQ uest+Dissertations+\%26+Theses+ Full+Text\&a

Richards, J. C. (2008). Teaching Listening and Speaking: From Theory to Practice. Language Teaching (Vol. 35). https://doi.org/10.1017/S02614448 
Volume 2 No. 1, Februari 2019

Universitas Banten Jaya

02211829

Sagala S. (2006). Konsep dan Makna

Pembelajaran. Bandung: CV.

Alfabeta.

Scarcella, R. C. (1978). Socio-Drama

For Social Interaction*. TESOL

Quarterly, 12(1), 41-46.

https://doi.org/10.2307/3585789

Sternberg, P., \& Garcia, A. (n.d.).

SOCIODRAMA: Who's in Your

Shoes? Second Edition.

Thornbury, S., \& Scott, T. (2012). How

to Teach Speaking - Scott

Thornbury. Journal of Education

and Practice (Vol. 3).

https://doi.org/10.1093/eltj/cci025.

Upstream, S. (2004). Towards a

Framework for, (March), 2-10.

https://doi.org/10.1007/0-306-

48727-6_7 